\begin{tabular}{|c|c|c|c|}
\hline $\begin{array}{c}\text { RESEARCH } \\
\text { Article }\end{array}$ & $\begin{array}{r}\text { ADVANCE RESEARCF } \\
\text { Volume } 8 \mid \text { Issue } 2 \mid \text { De }\end{array}$ & OCIAL SCIENCE & \\
\hline $0=$ & DOI: 10.15740/HAS/ARJSS/8.2/178-183 & Visit us : www.researchjournal.co.in & \\
\hline
\end{tabular}

\title{
Perceived attributes of home science technologies
}

Lakshmi M. Paloti* and Shobha Nagnur ${ }^{1}$

College of Rural Home Science, University of Agricultural Sciences, DHARWAD (KARNATAKA) INDIA

${ }^{1}$ Department of Extension and Communication Management, College of Rural Home Science, University of Agricultural Sciences, DHARWAD (KARNATAKA) INDIA

(Email: parvatipaloti@yahoo.in)

\section{ARTICLE INFO :}

$\begin{array}{lll}\text { Received } & : & 20.05 .2017 \\ \text { Revised } & : & 27.09 .2017 \\ \text { Accepted } & : & 13.10 .2017\end{array}$

\section{KEY WORDS :}

Perceived attributes, Technology, Home Science, Relative advantage, Compatibility

\section{HOW TO CITE THIS ARTICLE :}

Paloti, Lakshmi M. and Nagnur, Shobha (2017). Perceived attributes of home science technologies. Adv. Res. J. Soc. Sci., 8 (2) : 178-183, DOI: 10.15740/ HAS/ARJSS/8.2/178-183.

*Author for correspondence

\begin{abstract}
Women in rural areas suffer from many grave disadvantages and are subjected to great deal of hardship and drudgery. The jobs done by them are often physically arduous, time consuming and repetitive, resulting in fatigue and drudgery. So women need new technologies and practices to improve upon the old ones. Technology transfer and adoption process work simultaneously. The rate of adoption depends on the evaluation of innovation in terms of its perceived characteristics such as relative advantage, compatibility, complexity, trialability and observability. To study the perceived attributes of homestead technologies the present study was carried out during 2016-17 in the villages of Dharwad district of Karnataka state. The total sample size was 80 rural women. The study found that most of the respondents $(62.50 \%)$ perceived balanced diet as advantageous, compatible $(68.75 \%)$, easy to understand and use $(70.00 \%)$ and small scale trialability $(96.25 \%)$. Whereas 82.50 per cent of the respondents felt that the results of the technology are not observable. Similarly stain removal techniques and care and storage practices for clothes were perceived as favourable technologies.
\end{abstract}

